\title{
Molecules, morphometrics and new fossils provide an integrated view of the evolutionary history of Rhinopomatidae (Mammalia: Chiroptera)
} Pavel Hulva*1, Ivan Horáček ${ }^{1}$ and Petr Benda2,1

\author{
Address: ${ }^{1}$ Department of Zoology, Charles University, Viničná 7, CZ-128 44 Praha 2, Czech Republic and 2Department of Zoology, National \\ Museum (Natural History), Václavské náměstí 68, CZ-115 79 Praha 1, Czech Republic \\ Email: Pavel Hulva* - hulva@natur.cuni.cz; Ivan Horáček - horacek@natur.cuni.cz; Petr Benda - petr.benda@nm.cz \\ * Corresponding author
}

Published: 14 September 2007

BMC Evolutionary Biology 2007, 7:165 doi:10.1186/147|-2/48-7-165
Received: 6 December 2006

Accepted: 14 September 2007

This article is available from: http://www.biomedcentral.com/I47I-2/48/7//65

(c) 2007 Hulva et al; licensee BioMed Central Ltd.

This is an Open Access article distributed under the terms of the Creative Commons Attribution License (http://creativecommons.org/licenses/by/2.0), which permits unrestricted use, distribution, and reproduction in any medium, provided the original work is properly cited.

\begin{abstract}
Background: The Rhinopomatidae, traditionally considered to be one of the most ancient chiropteran clades, remains one of the least known groups of Rhinolophoidea. No relevant fossil record is available for this family. Whereas there have been extensive radiations in related families Rhinolophidae and Hipposideridae, there are only a few species in the Rhinopomatidae and their phylogenetic relationship and status are not fully understood.
\end{abstract}

Results: Here we present (a) a phylogenetic analysis based on a partial cytochrome $b$ sequence, (b) new fossils from the Upper Miocene site Elaiochoria 2 (Chalkidiki, Greece), which represents the first appearance datum of the family based on the fossil record, and (c) discussion of the phylogeographic patterns in both molecular and morphological traits. We found deep divergences in the Rhinopoma hardwickii lineage, suggesting that the allopatric populations in (i) Iran and (ii) North Africa and the Middle East should have separate species status. The latter species (R. cystops) exhibits a shallow pattern of isolation by distance (separating the Middle East and the African populations) that contrasts with the pattern of geographic variation in the morphometrical traits. A deep genetic gap was also found in Rhinopoma muscatellum (Iran vs. Yemen). We found only minute genetic distance between $R$. microphyllum from the Levant and India, which fails to support the sub/species distinctness of the Indian form ( $R$. microphyllum kinneari).

Conclusion: The mtDNA survey provided phylogenetic tree of the family Rhinopomatidae for the first time and revealed an unexpected diversification of the group both within $R$. hardwickii and $R$. muscatellum morphospecies. The paleobiogeographic scenario compiled in respect to molecular clock data suggests that the family originated in the region south of the Eocene Western Tethyan seaway or in India, and extended its range during the Early Miocene. The fossil record suggests a Miocene spread into the Mediterranean region, followed by a post-Miocene retreat. Morphological analysis compared with genetic data indicates considerable phenotypic plasticity in this group.

\section{Background}

The mammalian order Chiroptera serves as an excellent example of how molecular phylogenetics has influenced the taxonomy of a seemingly well resolved group. Genetic 
data invalidated the traditional subdivision of bats into suborders Megachiroptera and Microchiroptera when Teeling et al. [1-3] provided molecular evidence supporting sister position of one clade of microbats, Rhinolophoidea, with Megachiroptera. For that reason, the actual content of the Rhinolophoidea and phylogenetic structure of that clade became a matter of considerable interest. In the traditional view [4], Rhinolophoidea included Rhinolophidae, Hipposideridae, Megadermatidae, and Nycteridae. Molecular evidence $[2,5]$ has suggested that Nycteridae is not a member of that clade, but a sister group to Emballonuridae, whereas molecular data have brought two previously unassociated groups, Rhinopomatidae and Craseonycteridae, traditionally arranged together with Emballonuridae in the superfamily Emballonuroidea, into the Rhinolophoidea. The molecular taxonomy of Craseonycteridae has also been dealt with briefly [5], but Rhinopomatidae has remained one of the few mammalian families not re-examined from the perspective of molecular genetics (except for the data suggesting its position among Rhinolophoidea, close to Craseonycteridae and Megadermatidae $[3,6,7]$.

The lack of genetic data is particularly frustrating because Rhinopomatidae is, for several reasons, the most enigmatic group of extant bats. It is a monotypic family (composed of a single genus, Rhinopoma Geoffroy, 1813) with an exceptionally large geographic range covering a considerable part of tropical subsaharan Africa and most of the southern Mediterranean, Middle East, and southern Asia (from Morocco, Senegal and Kenya, through Arabia and the Middle East, to India, Thailand and Sunda Archipelago) $[4,8,9]$. Among monotypic families of mammals, only Rhinolophidae, Equidae and Manidae occupy such extensive geographic ranges. In contrast to rich data on the history and relationships of the other two families, no such information is available for Rhinopomatidae: there is no fossil record of the family (except for one occurrence in the Late Pleistocene of Israel [10]) and the relationship of the family to other bats has traditionally been unresolved. Rhinopomatidae bear a unique set of morphological plesiomorphies for which they were often regarded as the most primitive group of Microchiroptera close to the common ancestor of microbats and megabats [4,11-14]. After recent shaking of the chiropteran tree by molecular phylogenetics, rhinopomatids retained their basal position - in morphological respects they are still the most primitive clade within Rhinolophoidea and, thus, also the most primitive extant clade within the Yinpterochiroptera in the sense of Teeling et al. [3]. For all these reasons, Rhinopomatidae are an extremely attractive subject for a detailed study. Yet, these bats are quite rare throughout their range and recent records from many important regions are simply not available. Consequently, very few authors succeeded in comprehensive investigation of this taxon and its current taxonomy reflects numerous uncertainties about its actual content.

The present paper provides the first phylogenetic study on the family Rhinopomatidae based on the samples subsequently collected from the regions situated in the centre of the family range, i.e. Levant, Arabia, Iran, India and NE Africa (Figure 1). The results suggest that the taxonomic structure of the group is rather more complicated than commonly expected. In previous taxonomies, the genus Rhinopoma was divided into two to seven species and several local forms, for which at least 17 names are available. The detailed taxonomic review [see Additional file 1] demonstrates complicated and often opposing viewpoints and illustrates that attempts to reconstruct the structure of this family on the basis of classical markers alone were seldom persuasive. The most recent and comprehensive revision of the group [9] established a set of diagnostic morphological characters which splits the genus into four separate species sharing a broad range of sympatry. This arrangement has become the standard taxonomy [comp. $[9,15]]$ and it is adopted as the null hypothesis in the present paper (i.e. we refer to $R$. hardwickii, $R$. muscatellum and $R$. microphyllum lineages). The phylogroups revealed by our investigation are distinguished by Roman numerals (I-V), their nomenclatorial assignments summarized in Table 1 and explained in Additional file 1. We also report the first Neogene fossil record of Rhinopomatidae and discuss the history of this unique family of bats.

\section{Results \\ Morphometry}

Despite using a considerably extended set of morphometrical characters and applying multivariate morphometric analyses (based on 252 specimens, including types of 7 taxa, see [16] for details) our results revealed the same pattern of variation as reported in detail by Van Cakenberghe and De Vree [9], and Benda et al. [16,17]. Rhinopoma microphyllum, R. hardwickii, and R. muscatellum are distinct with partial overlap between the latter two (Figure 2). These phenotypic groups (or morphospecies) were found to be internally homogenous in their diagnostic characters, with $R$. hardwickii having the pronounced intraspecific variation, particularly in metrical components of body size [for details see Additional file 1].

\section{Molecular analyses}

We obtained 26 sequences from ingroup taxa of the first 402 bp of the cytochrome $b$ gene. Ninety-nine positions were variable, 93 were parsimony informative, and all mutations were base substitutions. The Rhinopoma samples analyzed fell into 15 haplotypes. The sequences exhibited a low level of saturation at the first and second codon positions, with a deflection from linearity at third 
Table I: Taxonomic structure of Rhinopomatidae: a tabular survey

\begin{tabular}{|c|c|c|c|}
\hline Molecular phylogroups & Range & Taxonomy & \\
\hline this paper & & traditional after Simmons 2005 & proposed this paper \\
\hline $\mathbf{I}$ & Iran & $\begin{array}{l}\text { R. hardwickii hardwickii } \\
\text { Gray, I83I }\end{array}$ & R. hardwickii ssp. $\mathbf{n}$. \\
\hline$*$ & India ( $T$ : Bengal) to Thailand & $\begin{array}{l}\text { R. hardwickii hardwickii } \\
\text { Gray, I83I }\end{array}$ & $\begin{array}{l}\text { R. hardwickii hardwickii } \\
\text { Gray, I83I }\end{array}$ \\
\hline$*$ & Sunda Archipelago & $\begin{array}{l}\text { R. hardwickii sondaicum van } \\
\text { Cakenberghe \& de Vree, I994 }\end{array}$ & $*$ \\
\hline$*$ & Sub-Saharan Africa & $\begin{array}{l}\text { R. hardwickii arabium } \\
\text { Thomas, } 1913\end{array}$ & $*$ \\
\hline Ila & Levant & $\begin{array}{l}\text { R. hardwickii arabium } \\
\text { Thomas, } 1913\end{array}$ & $\begin{array}{l}\text { R. cystops arabium } \\
\text { Thomas, } 1913\end{array}$ \\
\hline IIb & W Yemen $(T)$ & $\begin{array}{l}\text { R. hardwickii arabium } \\
\text { Thomas, } 1913\end{array}$ & $\begin{array}{l}\text { R. cystops arabium } \\
\text { Thomas, } 1913\end{array}$ \\
\hline IIb & Socotra & $\begin{array}{l}\text { R. hardwickii arabium } \\
\text { Thomas, } 1913\end{array}$ & $\begin{array}{l}\text { R. cystops arabium } \\
\text { Thomas, } 1913\end{array}$ \\
\hline IIc & Upper Egypt (T) & $\begin{array}{l}\text { R. hardwickii cystops } \\
\text { Thomas, } 1903\end{array}$ & $\begin{array}{l}\text { R. cystops cystops } \\
\text { Thomas, } 1903\end{array}$ \\
\hline IId & NE Libya & $*$ & $\begin{array}{l}\text { R. cystops cystops } \\
\text { Thomas, } 1903\end{array}$ \\
\hline III & SW Yemen & $\begin{array}{l}\text { R. muscatellum } \\
\text { Thomas, } 1903\end{array}$ & $\begin{array}{l}\text { R. sp. } \mathbf{n} \text {. } \\
\text { (aff. muscatellum) }\end{array}$ \\
\hline IV & SW Iran (Oman T) & $\begin{array}{l}\text { R. m. muscatellum } \\
\text { Thomas, I903 }\end{array}$ & $\begin{array}{l}\text { R. m. muscatellum } \\
\text { Thomas, I903 }\end{array}$ \\
\hline$*$ & Pakistan, SW India & $\begin{array}{l}\text { R. m. muscatellum } \\
\text { Thomas, } 1903\end{array}$ & $*$ \\
\hline$*$ & Lower Egypt ( $T)$ & $\begin{array}{l}\text { R. microphyllum microphyllum } \\
\text { (Brünnich, I782) }\end{array}$ & $\begin{array}{l}\text { R. m. microphyllum } \\
\text { (Brünnich, I782) }\end{array}$ \\
\hline $\mathbf{v}$ & Levant & $\begin{array}{l}\text { R. m. microphyllum } \\
\text { (Brünnich, I782) }\end{array}$ & $\begin{array}{l}\text { R. m. microphyllum } \\
\text { (Brünnich, I782) }\end{array}$ \\
\hline$*$ & SW Saudi Arabia $(T)$ & $\begin{array}{l}\text { R. m. asirensis } \\
\text { Nader \& Kock, } 1982\end{array}$ & $*$ \\
\hline $\mathbf{V}$ & India & $\begin{array}{l}\text { R. microphyllum kinneari } \\
\text { Wroughton, } 1912\end{array}$ & $\begin{array}{l}\text { R. m. microphyllum } \\
\text { (Brünnich, I782) }\end{array}$ \\
\hline$*$ & Thailand, N-Sumatra & $\begin{array}{l}\text { R. microphyllum sumatrae } \\
\text { Thomas, } 1903\end{array}$ & $*$ \\
\hline$*$ & Morocco to sub-Saharan Africa & $\begin{array}{l}\text { R. microphyllum } \\
\text { (Bruennich, I782) }\end{array}$ & $*$ \\
\hline$*$ & Kenya $(T)$ to Eritrea & $\begin{array}{l}\text { R. macinnesi } \\
\text { Hayman, } 1937\end{array}$ & $\begin{array}{l}\text { R. macinnesi } \\
\text { Hayman, } 1937\end{array}$ \\
\hline+ & Elaiochoria, Greece, MNI0-I3 & * & $\begin{array}{l}\text { † Rhinopoma } \\
\text { sp. n. (aff. hardwickii) }\end{array}$ \\
\hline
\end{tabular}

The molecular phylogroups covered by this paper are denoted by Roman numerals (I to $\mathrm{V}$ ), those not covered but referred to populations of expected taxonomical significance are denoted with an asterisk $\left(^{*}\right)$ similarly as absence of a taxonomic opinion. $(T)$ refers to a 'topotype' population, + to a fossil taxon. 


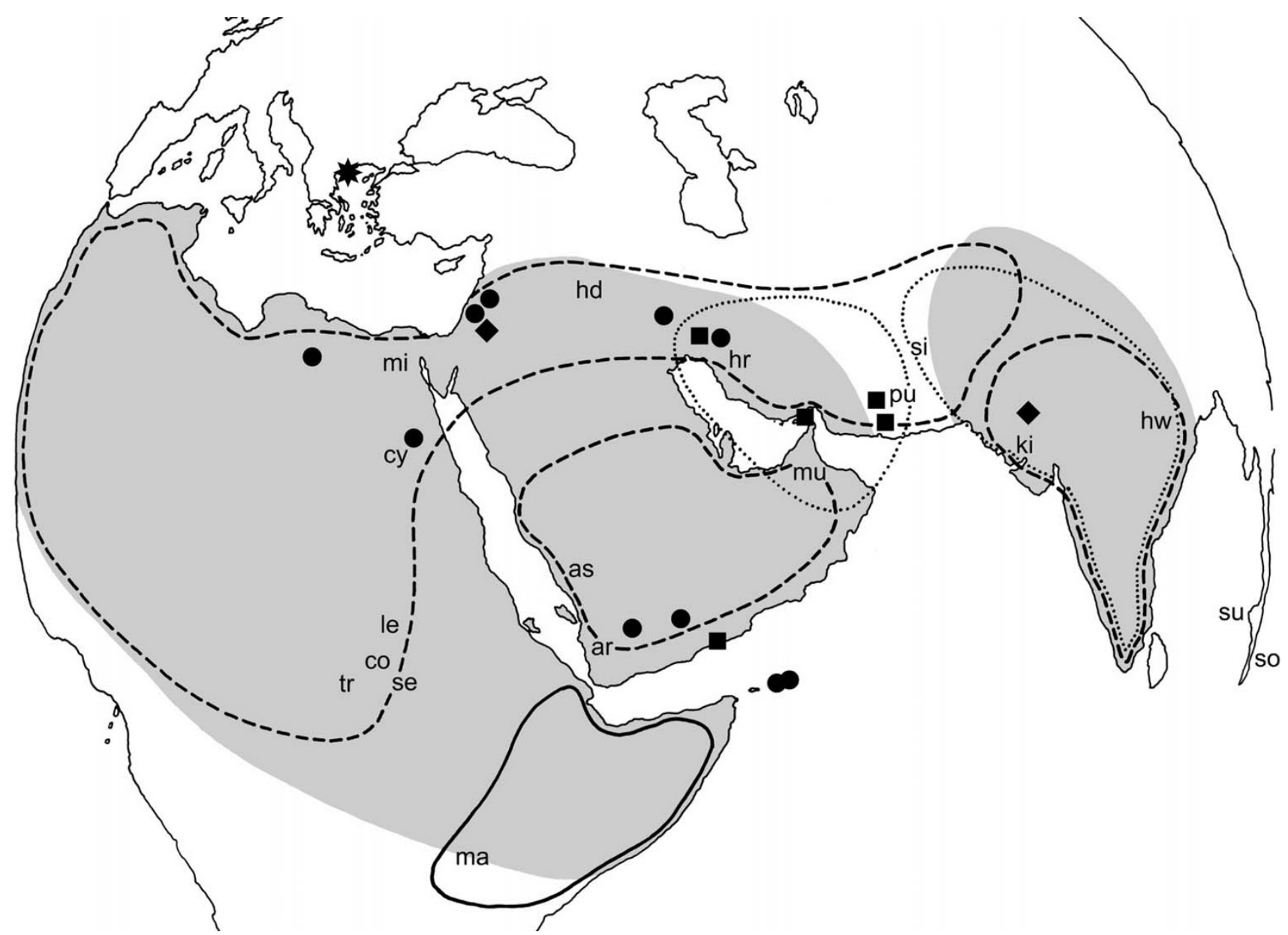

Figure I

Extant geographic distributions of species of rhinopomatid bats. (after $[9,56])$ : gray grid - $R$. hardwickii lineage, dashed line $-R$. microphyllum, dotted line $-R$. muscatellum lineage, full line $-R$. macinnesi. Localities of the DNA samples used in the present paper (comp. Table I): dots $-R$. hardwickii lineage, diamonds $-R$. microphyllum, squares $-R$. muscatellum lineage, asterisk - fossil Rhinopoma aff. Hardwickii. Type localities of individual named taxa: ar - arabium Thomas, 1913, as - asirensis Nader et Kock, 1982, co - cordofanicum Heuglin, 1877, cy - cystops Thomas, 1903, hd - hadithaensis Khajuria, 1988, hr - harrisoni Schlitter et DeBlase, 1974, hw - hardwickii Gray, I83I, ki - kinneari Wroughton, 1912, le - lepsianum Peters, I859, ma - macinnesi Hayman, 1937, mi - microphyllum Brünnich, 1782, mu - muscatellum Thomas, 1903, pu - pusillum Thomas, 1920, se - sennaariense Kock, 1969, si - seianum Thomas, 1913, so - sondaicum Van Cakenberghe et De Vree, 1994, su - sumatrae Thomas, 1903, tr - tropicalis Kock, 1969.

codon positions. We used a GTR + I + G distance correction model with gamma distribution shape parameter $=$ 1.70 .

All tree-building methods resulted in recognition of five clades, highly supported by bootstrap values and posterior probabilities (Figures 3 and 4): (clade I) Iranian haplotypes of R. hardwickii; (clade II) Middle Eastern and north African haplotypes of $R$. hardwickii; (clade III) Yemeni haplotypes of $R$. muscatellum; (clade IV) Iranian haplotypes of $R$. muscatellum; and (clade $\mathrm{V}$ ) haplotypes from the two available specimens of $R$. microphyllum.
The Middle Eastern and north African haplotypes of $R$. hardwickii (clade II) were subdivided into four geographic regions: (a) the Levant (Jordan and Syria); (b) Yemen and Socotra; (c) Upper Egypt; and (d) northern Libya. In contrast to the morphometric data that suggested considerable variation within that clade and support the distinctness of its traditionally recognized subspecies (viz. the large-sized $R . h$. arabium vs. the smaller $R$. h. cystops from the Upper Egypt) the genetic data demonstrated an unexpected homogeneity in clade II. A shallow but distinct divergence ( $\mathrm{p}$-distance $=3 \%$ ) was found between the North African haplotypes $(\mathrm{c}+\mathrm{d})$ and those from the 

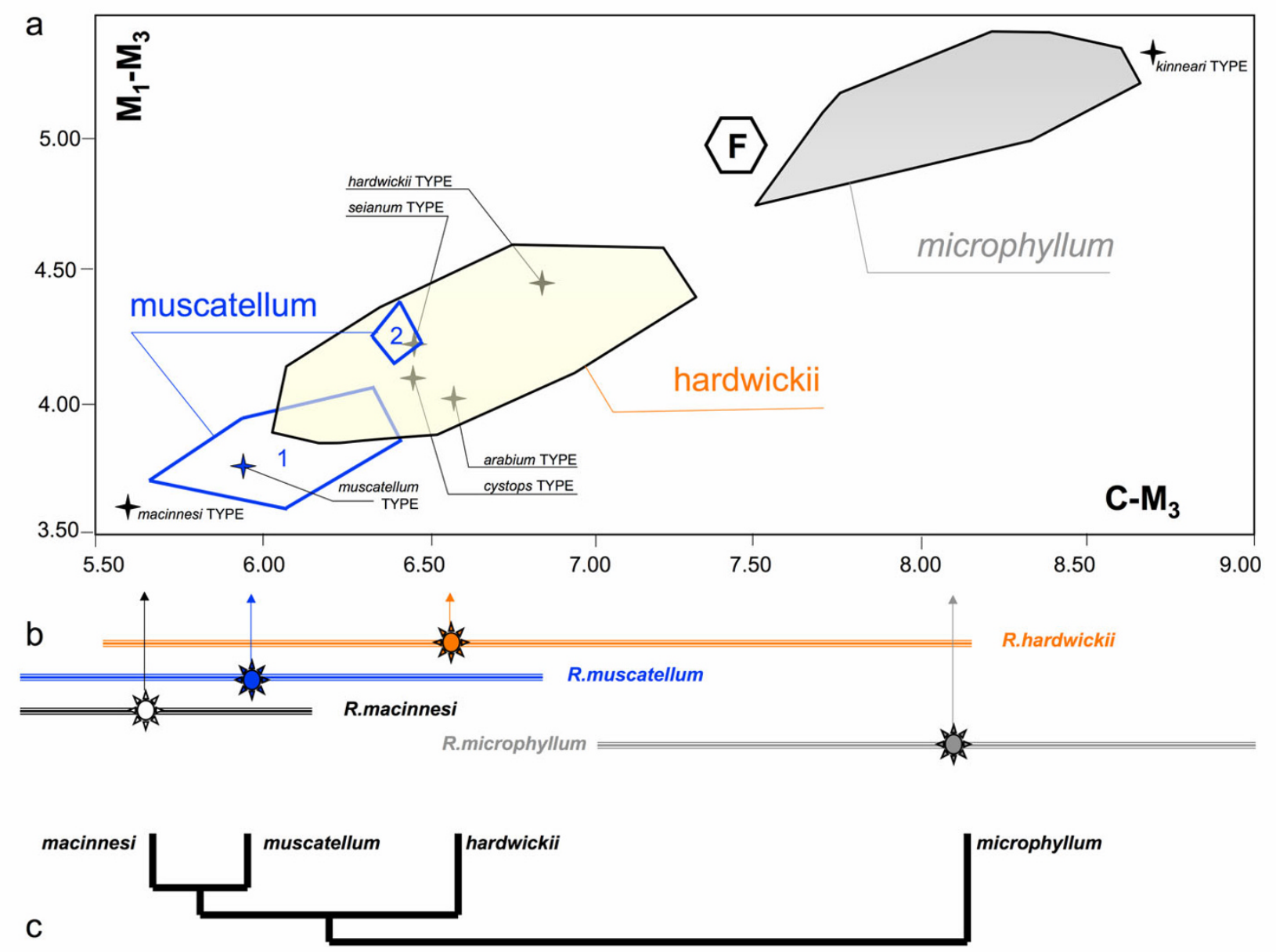

\section{Figure 2}

Morphometric characteristics of Rhinopomatidae. a - scatter plot of $C^{3}$ vs. $M^{1}-M^{3}$ in the sample examined in frame of this study $(n=252$, for further data see $[28,29])$ with position of the respective type specimens: note metric distinctness of the phenotypic forms hardwickii, microphyllum, muscatellum (I - Iran, 2 - Yemen) and position of the Miocene fossil from Elaiochoria 2, Greece; $\mathbf{b}$ - mean values and variation span of $\mathrm{CM}^{3}$ in four species of Rhinopoma as reported by Van Cakenberghe and De Vree [9], $\mathrm{n}=357,63,54$, I54; c - phylogenetic hypothesis suggested by morphometric characters.

Levant and Yemen $(a+b)$. No genetic difference was found between (c) and (d), which represent the most distinct forms of the clade in terms of morphometry (Figs. 2, 3 and 4 ), and only $0.5 \%$ genetic distance was found between (a) and (b), which are the most distant geographically. In contrast to the inner shallow cline of genetic variation, clade II is separated from the Iranian one (clade I) by a relatively deep genetic gap (8-9\%). Deep divergence was also found within the $R$. muscatellum lineage. The Yemeni haplotypes (clade III) and the haplotypes identified in Iran (clade IV) differ by a genetic distance of about $8-9 \%$. Although the two available specimens of R. microphyllum (clade V) represented very distant geographic regions (Levant vs. India) and the local forms have traditionally been considered to be distinct subspecies or even separate species ( $R$. microphyllum and $R$. kinneari), their genetic distance was very small $(0.5 \%)$.

Interestingly, reconstruction of the topology of deep branches within the family using outgroup rooting resulted in sister positions for R. microphyllum and R. muscatellum lineages (Figure 3 ). The molecular clock analysis provided the minimum estimate of radiation of the family, i.e. the separation of the R. hardwickii lineage, to be approximately 28.1 Ma. The next step, the splitting of the $R$. microphyllum and R. muscatellum lineages, was dated minimally to about $20.9 \mathrm{Ma}$. The split between clades I and II happened about $14.1 \mathrm{Ma}$, and the split between clades III and IV about 10.0 Ma. 

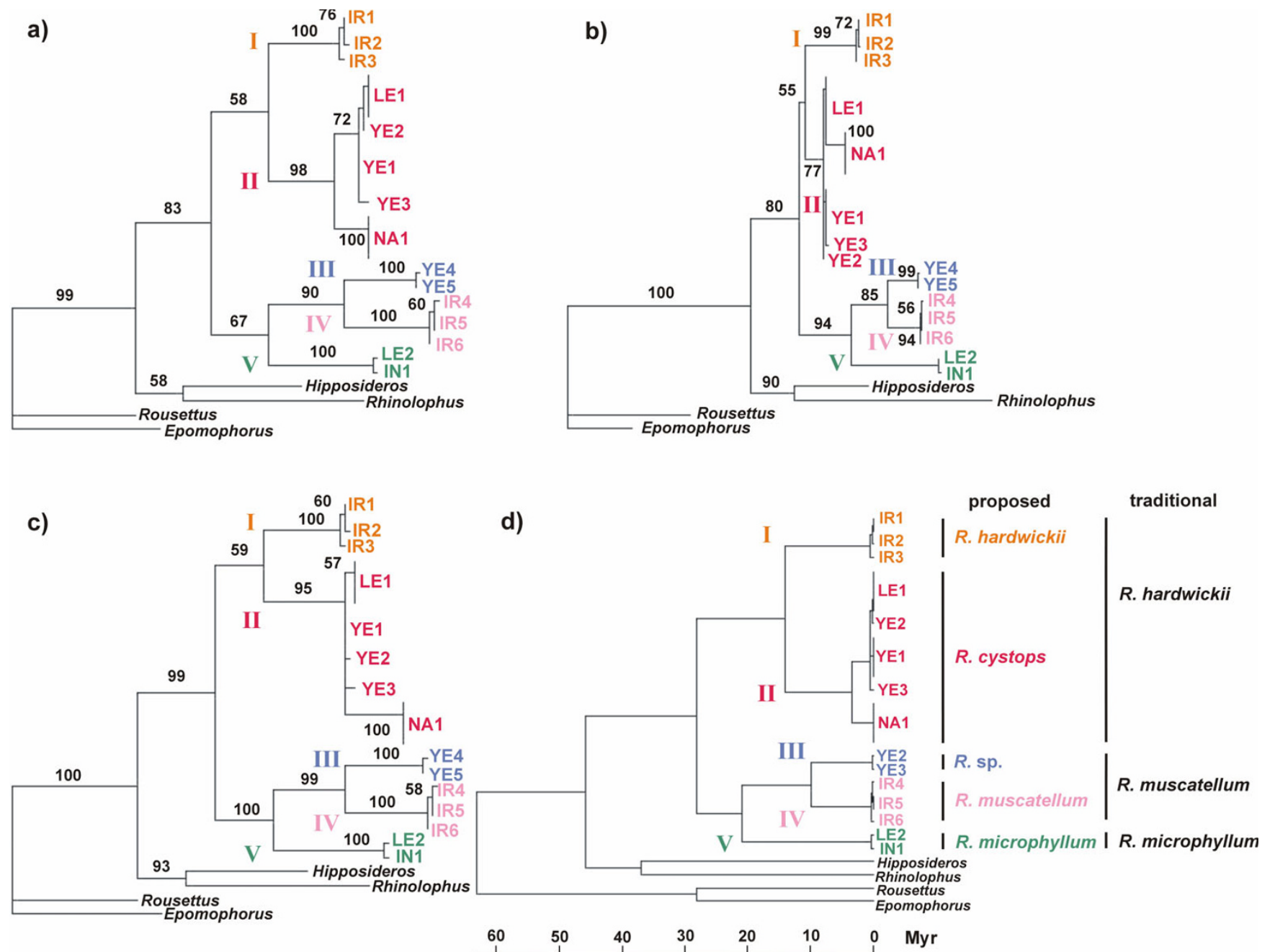

Figure 3

The topology of the rhinopomatid tree reconstructed from the $\mathbf{4 0 2}$ bp sequence of cytochrome $b$ gene. (a) maximum parsimony tree, length $=320$ mutations, consistency index excluding uninformative characters $=0.57$; retention index $=0.82$; rescaled consistency index $=0.50$ (b) maximum likelihood tree calculated under $\mathrm{GTR}+\mathrm{I}+\mathrm{G}$ model of sequence evolution, R-matrix $=(2209.1$ I 57, 5744.5737, I027.7924, 0.00I4, 23577.1543, I.0000), base frequencies $=(0.2945,0.3553$, $0.1347,0.2154)$ and gamma shape parameter $=1.6997, \log L=-1867.36$ (c) Bayesian tree with the same model of sequence evolution as in ML method (d) linearized maximum likelihood tree with the same model of sequence evolution as in ML method and molecular clock enforcement, $\log L_{\text {clock }}=-1884.45$. Numbers at the nodes correspond to 1000 replication bootstrap supports/posterior probabilities.

\section{Fossil record}

We found a rich sample of fossil remains unquestionably belonging to Rhinopoma sp. in a lithified infilling of a limestone karst cavity in Elaiochoria (Chalkidiki, Greece). The fauna indicates an early Turolian age, Late Miocene (MN 10-11), some 8-10 Ma. The analysis of the record [see Additional files 2 and 3] shows that: (i) the fossil material contains the all the morphological features that clearly distinguish Rhinopomatidae from other chiropteran families and, moreover, it falls within the variation of the Recent forms of the genus; (ii) the morphology corresponds to the Recent Rhinopoma hardwickii in the fine details of the dentition, in the shape of the distal epiphysis of the humerus, and in the shape of the proximal epiphysis of the radius; and (iii) the fossil material shows relatively large size variation and seems to exceed the range of variation in the Recent $R$. hardwickii, both in mean values and in the highest values (comp. Figure 2).

\section{Discussion}

Even with the present analysis, the family Rhinopomatidae remains an enigmatic group whose history, taxonomic content, patterns of variation and phylogenetic relationships are far of being properly comprehended. 


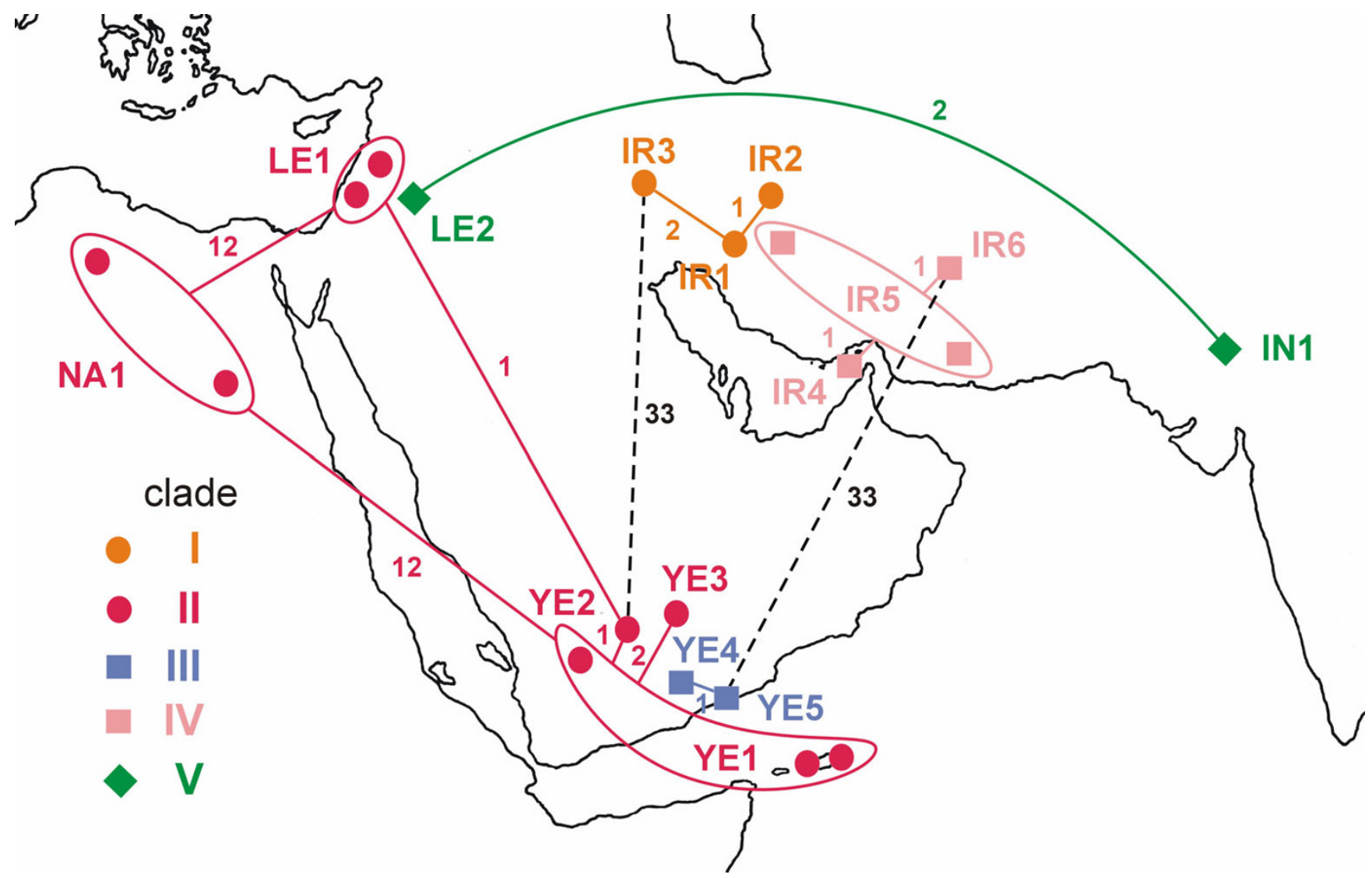

\section{Figure 4}

Geographic arrangements of parsimony networks connecting mtDNA haplotypes of bats from the genus Rhinopoma within clades revealed by tree building methods. Numbers at the branches indicate number of mutational steps. Dashed lines - the branches with minimum number of mutations between clades I and II and clades III and IV. The superimposition of the network in Iran, Yemen and Levant do not match geography exactly due to space limitations.

Nevertheless, the data summarized here substantially improve the scarce information on these subjects. We will discuss them in regard to (a) composition of the group, (b) possible phylogeographic patterns and (c) evolutionary history.

\section{Composition of Rhinopomatidae}

The analysis of the family Rhinopomatidae by Van Cakenberghe and De Vree [9] demonstrated that the genus consists of four species that differ in the shape of the palatal incision, the rostral ridges, the narial swellings, in the relative length of the tail, and in overall body size. The most distinctive in all these characters was $R$. microphyllum, whereas the differences between the remaining forms were less pronounced, exhibiting a broad measure of overlap in most metrical characters. Our analysis $(n=$ 252) provided the same picture (Figure 2). All of these data suggest that the major phenotypic divergence within the genus is that between $R$. microphyllum (including $R$. $m$. kinneari, $R$. m. sumatrae and $R . m$. asirensis) and the remaining forms, which thought to be closely related to a medium-sized species, R. hardwickii (Figure 2c), see [18].

Our mtDNA study confirmed the existence of the same three deep lineages recognized as morphospecies by Koopman [4], Hill [8] and Van Cakenberghe and De Vree [9] (another recognized species, R. macinnesi, was not included in our comparison). In addition, we found (i) deep divergence within the $R$. hardwickii lineage, (ii) incongruency between genetic and phenotypic phylogeographic patterns in clade II, (iii) deep divergence within the R. muscatellum lineage, (iv) a very shallow distance between the samples of $R$. microphyllum, suggesting an unexpected genetic homogeneity of that species. Last but not least, we demonstrated that (v) $R$. muscatellum (including the Yemeni population) is not a sister group of hardwickii, but of microphyllum. All these results contradict the standard view of the taxonomic structure of the family (Table 1), as well as of its distributional history [e.g. $[9,15]]$ and call for a brief comment. 


\section{Phylogeographic patterns}

(i) The genetic divergence found within $R$. hardwickii s.l.(= the $R$. hardwickii clade) splits the corresponding morphospecies into an Iranian clade I (R. hardwickii s.s.) and AfroArabian clade II (R. cystops). While there is a clear genetic continuity between the Levantine and Yemeni populations (e.g. haplotypes LE1, YE2, which are separated by approximately 3,000 km, differ by only 1 mutation step), the much smaller geographic distance between the Levantine and Iranian samples (approx. 1,200 km) is combined with deep genetic dissimilarities (the minimum genetic distance between haplotypes LE1 and IR3 is 34 mutation steps). We expect the divergence between these two groups represents real phylogeographic structure, a break crossing the Middle East from the north-west to the southeast. The boundary might be situated along the southern part of the Zagros Mountains, which represents a significant distribution barrier to many clades $[17,19]$. Unfortunately, knowledge of the distribution of bats in upper Mesopotamia is too scarce [19] to allow further discussion. Thus, we are unable to answer whether there is continuous distribution of haplotype frequencies with a clinal transition between geographic extremes, whether there are two allopatric ranges separated by a distinct geographic gap, or whether the ranges meet at a distinct zone of parapatry or sympatry. Because of the extent of the genetic dissimilarity, we are rather skeptical about the first alternative. Rather, we expect that clades I and II are entities separated at species level. We propose a separate species status for the two clades as per the genetic species concept [20-22] which sets a cutoff based on empirical data (cytochrome $b$ in the order Chiroptera) of about 5\% of corrected sequence divergence [e.g. [23,24]]. These two groups have almost double that divergence with $9 \%$ corrected divergence.

(ii) Within the clade II, a divergence of about 3\% separates African and Asian haplotypes of $R$. hardwickii. Within the African group, our genetic data contradict the groupings proposed by previous studies [see [8,9,17] and [25]], which stress a separate status for the populations of the central Sahara (including that of Upper Egypt). The genetic relatedness of these small bats to the largest form in Libya suggests an unexpected degree of phenotypic plasticity in these bats, apparently driven by temporary local conditions rather than by the genotypic backgrounds of the respective populations. Here, the selection pressures of the extreme conditions of desert habitats may have played a key role. A similar pattern of morphological bimodality has been observed in other desert or semidesert species of bats $[16,25,26]$, such as Taphozous nudiventris Cretzschmar, 1830, Rhinolophus clivosus Cretzschmar, 1828, Asellia tridens (Geoffroy, 1813), or Pipistrellus kuhlii (Kuhl, 1817), and such an explanation could be also invoked with respect to the smaller Arabian form, Rhinopoma microphyllum asiriensis Nader and Kock, 1983.

(iii) Our study has revealed that the morphospecies $R$. muscatellum is composed of two distinct clades: clade III in Yemen and clade IV in Iran and, supposedly, in Oman. This split is supported by morphometric differences (Fig. 2 ). Recent allopatry is more obvious in this case because clades III and IV are geographically isolated by the Arabian Desert. However, geographic positioning of major genetic breaks in $R$. hardwickii and $R$. muscatellum lineages coincides with this division (Fig. 4). With respect to the genetic species concept, it is reasonable to consider species status also for clades III and IV [for taxonomic rearrangements in the R. muscatellum lineage, see Additional file 1].

(iv) Considering the relatively deep genetic divergences within the morphospecies $R$. hardwickii and R. muscatellum (in the sense of Van Cakenberghe and De Vree [9]), the surprisingly low degree of geographic divergence of mtDNA in $R$. microphyllum calls for a comment. At least two qualities of this species are worth discussing in this connection: (i) its larger body size, and (ii) the well-pronounced seasonality of its life cycle and reproduction, including regular seasonal movements [e.g. [27]]. Both of these factors may contribute to increases in vagility and the rate of gene flow.

(v) The sister status of the R. microphyllum and R. muscatellum phylogroups contradicts traditional arrangements of the family where R. hardwickii and R. muscatellum are considered as the most closely related taxa based on similarities in narial morphology and body size (Figure 2c) $[18,28]$. The morphological polymorphism in genetically uniform populations of $R$. cystops (clade II) and R. microphyllum (clade I) does, however, indicate that the body size can undergo rapid rearrangement regardless whether in reaction to environmental conditions or as a character displacement due to interspecific interactions. Worth mentioning in this context is the large body size of the fossil Rhinopoma aff. R. hardwickii, which clearly exceeds the limits of the Recent $R$. hardwickii to which the fossil form is linked by its morphological characters. All these cases suggest that body size, traditionally applied as a significant character in taxonomy of the genus (because of considerable uniformity in other morphological characters) is controlled by ecological factors rather than by a strict taxon-specific developmental constraint.

\section{Evolutionary history}

The evolutionary history of Rhinopomatidae is a subject of particular interest, one which makes the group one of the most enigmatic clades of chiropterans. In the traditional view, Rhinopomatidae were regarded as the most primitive group of extant bats, the closest to the common 
ancestor of microbats and megabats [12,14]. Indeed, compared to other families of Yangochiroptera and Yinpterochiroptera, the family Rhinopomatidae exhibits a set of unique plesiomorphies: (i) the trochiter of the humerus (tuberculum minor) is small and does not permit the scapulo-humeral lock found in other bats; (ii) the wing tip index has the lowest value of all Chiroptera; (iii) medial phalanx of the second wing finger is complete and well-ossified; (iv) the last cervical and first throracic vertebrae are free (not fused as in other bats); (v) individual sacral vertebrae have distinct boundaries; (vi) the uropatagium is incomplete; (vii) the calcar is absent; (viii) tail is long and mouse-like, not entirely integrated to the uropatagium; (ix) the premaxillae are not attached to each other or to maxillae; and ( $\mathrm{x}$ ) the premaxillae are developed at the palatal plane only. A few of these characteristics (i, iv, vii) are shared with Craseonycteridae, while the others are unique among both Yangochiroptera and Rhinolophoidea, partly resembling the condition in Pteropodidae ( $i$, iii, iv, v, vi, ix, partly vii, viii, $x$ ).

In contrast to the major clades of Yinpterochiroptera [cf. $[3,15]]$, Rhinolophidae (1 genus, ca. 77 species), Hipposideridae (9 genera, ca. 81 species), and Pteropodidae (42 genera, ca 184 species), the family Rhinopomatidae is much less diversified [15]. In that respect it is similar to Megadermatidae (4 genera, 5 species) and Craseonycteridae (1 genus, 1 species), which are the sister clades of Rhinopomatidae according to the recent molecular data [3].

The present paper dates the beginning of radiation of extant clades of Rhinopomatidae (i.e. the separation of the $R$. hardwickii clade), to about $29 \mathrm{Ma}$ in the Oligocene. Nevertheless, the datum is apparently not relevant for the beginning of the family which arose with the earliest divergence of Rhinolophoidea, which molecular clock studies place at 50-55 My [3,7]in the Early Eocene. In contrast to other groups of Rhinolophoidea, whose early divergence is well represented in the fossil record, no such information is available for Rhinopomatidae and Craseonycteridae. In contrast to Creaseonycteriae, Rhinopomatidae occupies quite a large range comparable to that of other rhinolophoid families. At least for that reason, the absence of fossil record is unusual and calls for comment, at least as a background story to the discussion on meaning of the first Neogene record of the family reported in this paper.

Despite the fact that the fossil record of bats is sometimes regarded as being quite a poor [3], it is actually rich enough to enable discussions on major differences in phylogeny and early paleobiogeography of particular chiropteran clades at least in Europe and northern Africa. The remains of bats, including rich and taxonomically diversified assemblages, have been found in more than 130
European and North African sites of the Late Eocene, Oligocene and Early Miocene age [29-31] and current views on the structure of chiropteran fauna and the history of particular clades during that period [32] can be considered relevant and reliable. Among Rhinolophoidea, Hipposideridae and Rhinolophidae are particularly rich in their fossil record and, with a number of divergent clades, they have predominated the fossil assemblages in Europe, Africa, and even Australia since the Late Eocene [32-34]. In contrast, no relevant fossil record is available for Craseonycteridae or (until this paper) for Rhinopomatidae. The situation with Megadermatidae is more intricate. The first evidence of appearance of true Megaderma in Europe comes from the Upper Oligocene (MP25 Carrascosa del Campo, Spain [35]; MP29 Saint-Victor-la-Coste, France [36]; MP 29 Herrlingen 9, Germany [37]) and a number of further records are of Miocene and Pliocene age [37]. In contrast to hipposiderids or nycterids, the family is absent from African Oligocene sites (including Fayum or Taquah in Oman $[30,38]$ but appears in the Lower Miocene of Thailand and even in Australia [39]. The Late Eocene to Early Oligocene genus Necromantis, often regarded as a megadermatid [31], differs from true megadermatids in several characters (including basisphenoidal pits, a key character of emballonurids, which is invariably absent in rhinolophoids) and most probably does not belong to that stock. The absence of Rhinopomatidae and the late first appearance datum of Megadermatids in the fossil record contrasts with the fact that other groups such as Emballonuridae, Hipposideridae, Rhinolophidae, Molossidae, and Vespertilionidae s.l. are constant components of the western Palaearctic and African fossil record since the late Eocene $[31,29,40]$. All had already produced a number of subclades during the Oligocene and Early Miocene $[32,37,41]$. The absence of any rhinopomatids in the fossil record is surprising because these bats differ from all others in a number of conspicuous dental and skeletal specificities by which they are easily distinguishable, even based on a single fragmentary tooth. Moreover, rhinopomatids are cave-dwellers, which predisposes them to be particularly common in the fossil record. Under such conditions their absence in fossil record can be interpreted as a real fact which most probably reflects actual absence of the group in the western Palaearctics prior to the Miocene.

The fact that the phenotype of Rhinopomatidae (similarly as in Craseonycteridae) is composed almost exclusively of the ancestral characters not affected by adaptive rearrangements common in other chiropteran families, in contrast to other chiropteran families [42], suggests that (i) the clade was established at a very early stage of chiropteran radiation (prior to the first appearances of modern families, in the Middle Eocene or earlier), and (ii) that rhinopomatids were relatively little affected by the same adaptive 
processes that affected other all bat families, which all evolved under constant competitive pressure from other microbat clades. The latter could happen only under conditions of long-term isolation of rhinopomatids from other bats. An analogous case is the extinct clades of Palaeochiropterygidae and Hassianycteridae, which extensively diversified in Central Europe during geographic isolation of that region in the Early and Middle Eocene $[43,44]$. These endemic groups were radically replaced by modern bat families soon after their invasion during the Late Eocene "grand coupure" [33]. The respective modern clades, Hipposideridae, Rhinolophidae, modern Emballonuridae, Vespertilionidae, Molossidae [comp. [29,31]], arrived either from Africa and or Asia, and their early radiations most probably took place there (comp. also [3] for molecular support to that hypothesis). The complete absence of rhinopomatids in the fossil record and the lack of coevolutionary influence on their phenotype suggest that this group was absent in Europe and probably also in Africa and Asia. Of course, Tanzanycterididae with Tanzanycteris mannardi from the Early Lutetian (46 Ma) of Tanzania [45] may ultimately be shown to be closely related to Rhinopomatidae. Unfortunately the characters available in the specimen of Tanzanycteris provide only tentative support for such a possibility (e.g. enlarged cochlea, a lack of scapulo-humeral lock which is, common to all other Eocene bats).

The first appearance datum of Megadermatidae s. str. is nearly synchronous with dramatic rearrangements of the European mammalian fauna, with the appearance of the Asiatic elements (e.g. Cricetidae) and a considerable contribution of non-mammalian taxa from the Indian and Indomalaysian provinces such as Gavialosuchus, Tomistoma, and Varanidae. The spread of these taxa into Europe has been dated to ca. $18 \mathrm{Ma}$ [46]. Recent paleogeographic analyses $[47,48]$ supplement the picture with further data that show continuity between the Mediterranean-Iranian and the eastern Indian-east African marine provinces until the final disappearance of the Western Tethyan seaway in the Early Miocene.

In case of Rhinopomatidae, no such evidence is available. The Late Miocene fossil record reported in this paper is apparently not related to the early history of the clade. Nevertheless, the results of molecular studies provide valuable information. The first dated split within the family (R. hardwickii s.l. vs. R. microphyllum-muscatellum: 28.1 Ma) shows no phylogeographic signal - both clades are broadly sympatric. Nevertheless, the next cladogenetic events (R. microphyllum vs. R. muscatellum: $20.9 \mathrm{Ma}$ ) have clear phylogeographic correlates. In the later events, the phylogeographic signals are even more pronounced: clades I vs. II (14.1 Ma): Iran vs. Levant to Africa, and clades IV and III (10 Ma): Iran vs. Yemen. According to tra- ditional biogeography $[49,50]$, the region with the largest concentration of taxonomic diversity is the most likely candidate for being the source area of the group in question. In the case of rhinopomatids, the present results would suggest Iran to be such a candidate. At the very least, these results suggest that Iran was an area of paleoendemism that played host for the ancestral clades more than $11 \mathrm{Ma}$ ago. Nevertheless, the terrestrial conditions appeared in the respective region first at the time of Oligocene/Miocene transition [51] and thus the source area of the clades that colonized at in that time was apparently situated in other regions.

Based on the above discussion, we proposed the following biogeographic hypothesis (Figure 5):

(i) Rhinopomatidae originated during the Eocene from the early diversification of rhinolophoid bats that remained isolated from competitive pressure of other chiropteran clades somewhere in the archipelago south of the Western Tethyan seaway or in India.

(ii) The group evolved in isolation until the Oligocene when the marine barrier between the Mediterranean and Indian Tethys provinces disappeared. Endemic adaptation to major chiropteran foraging strategies in ancient rhinolophoids produced clades whose ecomorphological design was much different corresponding foraging specialists on neighbouring continents. Some of those ancient clades survive now: rhinopomatids as aerial foragers, craseonycterids as foragers of small prey in cluttered habitats, and megadermatids as ground gleaners.

(iii) The land between Iran and western India, uplifted during the Oligocene, was subsequently invaded by rhinopomatids and became the key location of their early Neogene radiation. The westward invasion was from the south, then to Arabia (which came in contact with the Iran belt some $20 \mathrm{Ma}$ ago) with the R. muscatellum lineage, and perhaps later to the northern part of the Iran and to the Mediterranean with the $R$. hardwickii lineage. The paleobiogeographic analyses of rodents [52] suggest that the respective westward migrations may begun even much earlier - in the late Eocene and early Oligocene via archipelagos south of the Western Tethyan seaway.

(iv) Extension of the paleogeographic and paleoenvironmental rearrangements of the Middle East during the Vallesian and Turolian stage, ca. $11 \mathrm{Ma}$ [compare with [53-55]], fixed the already established divergences among the clades within both $R$. hardwickii and R. muscatellum lineages.

(v) The extension of the range of the large-sized Indian $R$. microphyllum may have appeared quite late after these 


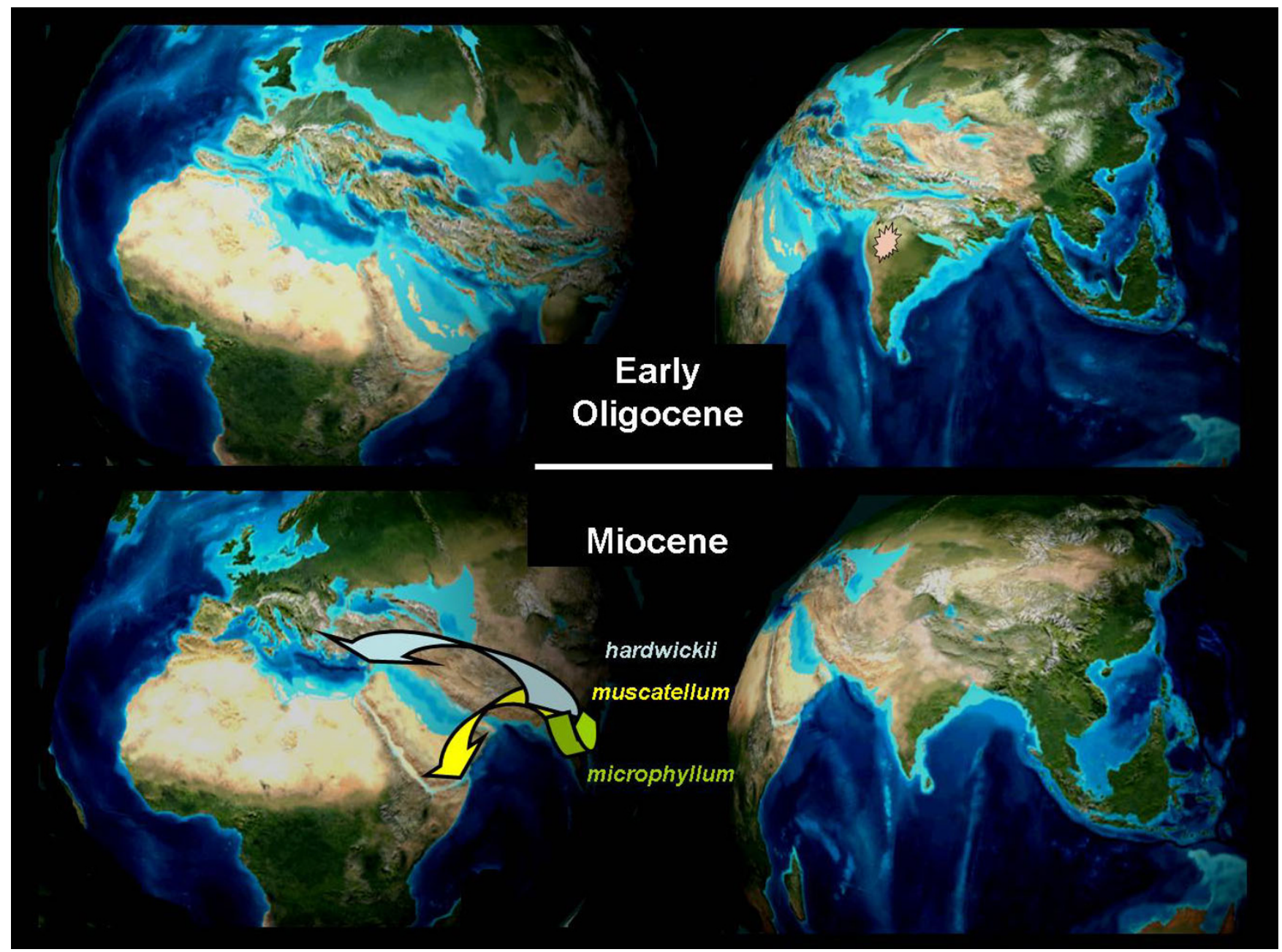

Figure 5

Palaeogeographic situation of the Indian-Middle East region in the Late Eocene/Lower Oligocene (35 My) and in the Miocene (20 My), with expected expansion pathways of three major lineages (sensu Van Cakenberghe and De Vree [9]) of the family. The paleogeographic background maps were compiled by Ron Blakey, Department of Geology, Northern Arizona University, Flagstaff [66]. Printed with permission.

events, possibly even during the Quaternary under the influence of more pronounced seasonality in the climate [53].

\section{Conclusion}

This first genetic study dealing with the family Rhinopomatidae has enabled us to put forward phylogenetic hypotheses that differ considerably from the concepts resulting of previous morphological studies. Contrary to what was expected, we found deep allopatric genetic divergences within the $R$. hardwickii and $R$. muscatellum lineages, which suggests a separate species status for the Afro-Arabian branch of R. hardwickii (i.e. R. cystops) and for the Yemeni branch of $R$. muscatellum. In contrast, we found a surprisingly high genetic homogeneity in $R$. microphyllum $(0.5 \%$ of genetic distance over $3,400 \mathrm{~km}$ of geographic distance). Morphological polymorphism in the genetically uniform $R$. cystops and R. microphyllum and the characteristics of the fossil taxon suggests plasticity of body size in this group. Considering information on the Recent and past ranges and the genealogy of the group, we expect that history of the family included (i) an early isolation in archipelago south of Western Tethyan seaway or in India, (ii) a northward- and westward spread into Mediterranean after disappearance of the marine barrier in the Late Oligocene and (iii) retreat from there after the Miocene climatic optimum.

\section{Methods \\ Taxonomic sampling}

We examined both museum specimens and individuals collected during our field excursions. The material exam- 
ined for morphometric analysis $(n=252)$ covered all parts of the range (except East Asia), included nearly all nominal taxa, and included the holotypes of $R$. hardwickii Gray, 1831, R. lepsianum Peters, 1859, R. kinneari Wroughton, 1912, R. cystops Thomas, 1903, $R$. arabium Thomas, 1913, R. muscatellum Thomas, 1903, R. seianum Thomas, 1913, $R$. pusillum Thomas, 1920, and R. macinnesi Hayman, 1937. The molecular analyses were undertaken with 26 specimens representing three nominal species, namely $R$. microphyllum, R. hardwickii, and R. muscatellum (Table 2, column 1; Figure 1). Species identification followed the criteria summarized by Van Cakenberghe and De Vree [9] and Corbet and Hill [56], aided by direct comparisons with other material included in morphometric comparisons. Voucher specimens have been deposited in the collections of the National Museum, and the Department of Zoology, Faculty of Science, Charles University, both Prague, Czech Republic. Specimens were selected in order to provide a reliable geographic and taxonomic coverage of the range, and include the holotype material of $R$. microphyllum, R. kinneari, R. cystops, $R$. arabium, and $R$. pusillum. For further details concerning the specimens (including the morphometrical data), see $[16,17]$. Fossils reported in this paper are deposited in the collections of Department of Zoology, Charles University in Prague [see Additional file 2].

The present paper is the first molecular assay on taxonomy of Rhinopomatidae. All other studies on this group (as well as a preliminary routine identification of our own material) have been based on results of morphometric comparisons. Rhinopomatid taxa have been traditionally diagnosed by morphometric specificities, and distinguish these morphology-based taxa from genetic grouping by denoting them as "morphospecies".

\section{Molecular analysis}

We extracted total genomic DNA from ethanol-preserved tissues and sequenced $402 \mathrm{bp}$ of the 5 '-end of the cytochrome $b$ gene (according protocols published in [5]). Accession nos. [GenBank: DQ337480 - DQ337502, EF443165 - EF443167]. As multiple outgroup, we used representatives of the clade Yinpterochiroptera Teeling et al., 2005: Hipposideros bicolor [AF358131], Rhinolophus hipposideros [AF044660], Rousettus leschenaulti [AF044662] and Epomophorus wahlbergi [ $\underline{\mathrm{AF} 044642]}$.

The sequences were aligned by eye and the dataset was processed in PAUP 4.0b10 [57]. We tested the cladistic information content and saturation level [58] by saturation tests [59]. We have inferred the model of sequence evolution in Modeltest 3.7 [60] using a hierarchical likelihood ratio test. The resulting model was used to correct distances and for maximum likelihood and Bayesian analyses. We performed distance analyses to quantify genetic gaps within the clade. We computed pairwise p-distances (Table 1, lower triangle, values used in the text to demonstrate genetic distances) and corrected distances among ingroup haplotypes. We used GTR (model fitting best our data according to Modeltest; Table 3, upper triangle) and $\mathrm{K} 2 \mathrm{P}$ (distance used in previous studies on bat species [e.g. $[23,24,61]])$ corrections. The results of both corrected distance analyses were almost identical. The data were ordered by computing trees using several approaches: neighbor-joining, maximum parsimony (heuristic search with 100 random-addition sequences and the TBR branch-swapping algorithm; Figure 3a) and maximum likelihood (Figrue $3 \mathrm{~b}$ ). For the Bayesian analysis (performed in MrBayes 3.1 [62]; Figure 3c) we used GTR + I + $\mathrm{G}$ model, flat priors and random starting tree. We ran four chains in MCMC analysis with 10,000,000 generations and sampled trees every 100 generations. The stationary was inspected via log probability plots and the convergence diagnostics for model parameters and burn-in was used to discard first 1,000,000 generations. We repeated the Bayesian run to test for convergence. The robustness of the topologies obtained was tested by bootstrap using 1,000 replicates, and by computing posterior probabilities. We estimated the approximate dates of divergences (Figure 3d) using the linearized tree approach [63]. The difference in $\log$-likelihoods (2 [ $\log L-\log L_{\text {clock }}$ ], [64]) of non-clock like $(\log L=-1867.36)$ and clock-like $\left(\log L_{\text {clock }}\right.$ $=-1884.45)$ trees compared against $\chi^{2}$ distribution $(\mathrm{df}=$ $\mathrm{N}_{\text {taxa }}$ - 2) was not significant at the 5\% level (19.50), and thus the molecular clock could not be rejected. Since there is a lack of fossils that would be useful for calibration of the tree within the family, we used a $37 \mathrm{Ma}$ for Rhinolophus-Hipposideros split (37 Myr, $[43,65])$ to calibrate the tree (since the age of the fossil represents the minimum date of the fossil lineage occurrence, we provided estimates of minimum dates of divergences based on $\mathrm{ML}$ branch lengths). Geographic arrangements of parsimony networks were used to visualize phylogeographic pattern among haplotypes (Figure 4). We visualize the branches with minimum of mutational steps within clades revealed by tree building methods. The shortest connection between clades clades I and II and clades III and IV was displayed to indicate phylogeographic breaks within traditional $R$. hardwickii and R. muscatellum.

\section{Competing interests}

The author(s) declares that there are no competing interests.

\section{Authors' contributions}

PH performed molecular and phylogenetic analyses and wrote the first version of the manuscript. IH initiated the study, discovered the fossil specimen, and contributed to the paleontological and paleobiogeographic parts of the manuscript. PB collected most of material, performed 
Table 2: Specimen and sequence information

\begin{tabular}{|c|c|c|c|c|c|c|}
\hline Species - traditional & Species (clade) - proposed & Haplotype & State & Site (Region) & Collector & Accession No. \\
\hline R. hardwickii & R. hardwickii (I) & $|R|$ & Iran & Izeh (Khuzestan) & P. Benda, M. Andreas, A. Reiter, M. Uhrin & $\underline{\mathrm{DQ} 337480}$ \\
\hline R. hardwickii & R. hardwickii (I) & IR2 & Iran & Izeh (Khuzestan) & P. Benda, M. Andreas, A. Reiter, M. Uhrin & DQ337482 \\
\hline R. hardwickii & R. hardwickii (I) & IR3 & Iran & Jelugir (Lorestan) & P. Benda, M. Andreas, A. Reiter, M. Uhrin & $\underline{\mathrm{DQ} 337483}$ \\
\hline R. hardwickii & R. cystops (II) & LEI & Jordan & Tabaqat Fahl (Irbid) & P. Benda & $\underline{\mathrm{DO} 337484}$ \\
\hline R. hardwickii & R. cystops (II) & LEI & Jordan & Tabaqat Fahl (Irbid) & P. Benda & $\underline{\mathrm{DO} 337485}$ \\
\hline R. hardwickii & R. cystops (II) & LEI & Syria & Nimrod Fortress (Golan Heights) & P. Benda & $\underline{\mathrm{DO} 337486}$ \\
\hline R. hardwickii & R. cystops (II) & LEI & Syria & Nimrod Fortress (Golan Heights) & P. Benda & $\underline{\mathrm{DQ} 337487}$ \\
\hline R. hardwickii & R. cystops (II) & YEI & Yemen & Wadi Zerig (Socotra) & V. Bejcek & $\underline{\mathrm{DQ} 337488}$ \\
\hline R. hardwickii & R. cystops (II) & YEI & Yemen & Timre (Socotra) & P. Benda, A. Reiter & $\underline{\mathrm{DO} 337489}$ \\
\hline R. hardwickii & R. cystops (II) & YEI & Yemen & Wadi Zerig (Socotra) & P. Benda, A. Reiter & $\underline{\mathrm{DO} 337490}$ \\
\hline R. hardwickii & R. cystops (II) & YE2 & Yemen & Old Ma'arib (Ma'arib) & P. Benda & EF443166 \\
\hline R. hardwickii & R. cystops (II) & YE3 & Yemen & Al Azhlaniya (Hadramawt) & P. Benda & EF443167 \\
\hline R. hardwickii & R. cystops (II) & NAI & Libya & Al Jaghbub (Cyrenaica) & P. Benda, M. Andreas, V. Hanak, A. Reiter, M. Uhrin & $\underline{\mathrm{DO} 337491}$ \\
\hline R. hardwickii & R. cystops (II) & NAI & Egypt & Karnak (Qena, Upper Egypt) & P. Munclinger, P. Nova & $\underline{\mathrm{DO} 337492}$ \\
\hline R. hardwickii & R. cystops (II) & NAI & Libya & Al Jaghbub (Cyrenaica) & P. Benda, M. Andreas, V. Hanak, A. Reiter, M. Uhrin & $\underline{\mathrm{DO} 337493}$ \\
\hline R. hardwickii & R. cystops (II) & NAI & Libya & Al Jaghbub (Cyrenaica) & P. Benda, M. Andreas, V. Hanak, A. Reiter, M. Uhrin & $\underline{\mathrm{DO} 337494}$ \\
\hline R. cf. muscatellum & R. sp. (III) & YE4 & Yemen & Ash-Shehir (Hardamawt) & D. Basuwayd & $\underline{\mathrm{DO} 337495}$ \\
\hline R. cf. muscatellum & R. sp. (III) & YE5 & Yemen & Ash-Shehir (Hardamawt) & D. Basuwayd & $\underline{\mathrm{DO} 337496}$ \\
\hline R. muscatellum & R. muscatellum (IV) & IR4 & Iran & Hormoz Isl. (Hormozgan) & P. Benda, A. Reiter & $\underline{\mathrm{DQ} 337497}$ \\
\hline R. muscatellum & R. muscatellum (IV) & IR5 & Iran & Izeh (Khuzestan) & P. Benda, M. Andreas, A. Reiter, M. Uhrin & $\underline{\mathrm{DQ} 337498}$ \\
\hline R. muscatellum & R. muscatellum (IV) & IR5 & Iran & Pir Sohrab (Baluchestan) & P. Benda, A. Reiter & $\underline{\mathrm{DQ} 337499}$ \\
\hline R. muscatellum & R. muscatellum (IV) & IR6 & Iran & Kahiri (Baluchestan) & P. Benda, A. Reiter, J. Obuch & $\underline{\mathrm{DQ} 337500}$ \\
\hline R. microphyllum & R. microphyllum (V) & INI & India & Rajastan & T. Adamova & DQ337502 \\
\hline
\end{tabular}


Table 3: P-distances (lower triangle) and corrected distances (GTR model, upper triangle) among haplotypes

\begin{tabular}{|c|c|c|c|c|c|c|c|c|c|c|c|c|c|c|c|c|c|}
\hline species (clade) & & haplotype & I & 2 & 3 & 4 & 5 & 6 & 7 & 8 & 9 & 10 & 11 & 12 & 13 & 14 & 15 \\
\hline \multirow[t]{3}{*}{ R. hardwickii (I) } & I & IRI & & 0,002 & 0,005 & 0,099 & 0,094 & 0,097 & 0,100 & 0,103 & 0,145 & 0,142 & 0,151 & 0,148 & 0,145 & 0,166 & 0,166 \\
\hline & 2 & IR2 & 0,002 & & 0,008 & 0,103 & 0,097 & 0,100 & 0,103 & 0,106 & 0,142 & 0,139 & 0,147 & 0,144 & $0,|4|$ & 0,162 & 0,162 \\
\hline & 3 & IR3 & 0,005 & 0,007 & & 0,093 & 0,093 & 0,091 & 0,099 & 0,102 & 0,143 & 0,140 & 0,148 & 0,145 & 0,142 & 0,163 & 0,163 \\
\hline \multirow[t]{5}{*}{ R. hardwickii (II) } & 4 & LEI & 0,090 & 0,092 & 0,085 & & 0,005 & 0,003 & 0,010 & 0,031 & 0,144 & 0,141 & 0,146 & 0,143 & 0,146 & 0,159 & 0,159 \\
\hline & 5 & YEI & 0,085 & 0,087 & 0,085 & 0,005 & & 0,003 & 0,005 & 0,031 & 0,150 & 0,147 & 0,146 & 0,143 & 0,146 & 0,159 & 0,159 \\
\hline & 6 & YE2 & 0,087 & 0,090 & 0,082 & 0,002 & 0,002 & & 0,008 & 0,034 & 0,147 & 0,144 & 0,143 & 0,140 & 0,143 & 0,156 & 0,156 \\
\hline & 7 & YE3 & 0,090 & 0,092 & 0,090 & 0,010 & 0,005 & 0,007 & & 0,036 & 0,149 & 0,146 & 0,152 & 0,150 & 0,152 & 0,166 & 0,166 \\
\hline & 8 & NAI & 0,092 & 0,095 & 0,092 & 0,030 & 0,030 & 0,032 & 0,035 & & 0,153 & 0,150 & 0,138 & 0,135 & 0,138 & 0,173 & 0,173 \\
\hline \multirow[t]{2}{*}{ R. muscatellum (III) } & 9 & YE4 & 0,127 & 0,124 & 0,124 & 0,124 & 0,129 & 0,127 & 0,129 & 0,132 & & 0,002 & 0,100 & 0,097 & 0,095 & 0,154 & 0,161 \\
\hline & 10 & YE5 & 0,124 & 0,122 & 0,122 & 0,122 & 0,127 & 0,124 & 0,127 & 0,129 & 0,002 & & 0,097 & 0,095 & 0,092 & $0,|5|$ & 0,158 \\
\hline \multirow[t]{3}{*}{ R. muscatellum (IV) } & 11 & IR4 & 0,132 & 0,129 & 0,129 & 0,127 & 0,127 & 0,124 & 0,132 & 0,122 & 0,090 & 0,087 & & 0,003 & 0,005 & 0,168 & 0,168 \\
\hline & 12 & IR5 & 0,129 & 0,127 & 0,127 & 0,124 & 0,124 & 0,122 & 0,129 & 0,119 & 0,087 & 0,085 & 0,002 & & 0,003 & 0,165 & 0,165 \\
\hline & 13 & IR6 & 0,127 & 0,124 & 0,124 & 0,127 & 0,127 & 0,124 & 0,132 & 0,122 & 0,085 & 0,082 & 0,005 & 0,002 & & 0,162 & 0,162 \\
\hline \multirow[t]{2}{*}{ R. microphyllum (V) } & 14 & LE2 & 0,142 & 0,139 & 0,139 & 0,137 & 0,137 & 0,134 & 0,142 & 0,147 & 0,132 & 0,129 & 0,142 & 0,139 & 0,137 & & 0,005 \\
\hline & 15 & INI & 0,142 & 0,139 & 0,139 & 0,137 & 0,137 & 0,134 & 0,142 & 0,147 & 0,137 & 0,134 & 0,142 & 0,139 & 0,137 & 0,005 & \\
\hline
\end{tabular}

morphometric analyses, and wrote the taxonomy parts of the manuscript. All authors have read and approved the final version.

\section{Additional material}

\section{Additional file 1}

Taxonomic structure of Rhinopomatidae. Morphospecies vs. molecular phylogenetics.

Click here for file

[http://www.biomedcentral.com/content/supplementary/1471-

2148-7-165-S1.doc]

\section{Additional file 2}

The late Miocene Rhinopoma aff. hardwickii from Elaiochoria, Greece. Detailed information about the new fossil record is provided. Click here for file

[http://www.biomedcentral.com/content/supplementary/14712148-7-165-S2.png]

\section{Additional file 3}

Selected specimens of the fossil Rhinopoma aff. hardwickii from Elaiochoria 2, Chalkidiki, Greece compared to Recent R. cystops. 1: $M / 1-M / 3,2: P / 3-M / 3,3: M / 3,4: P / 4,5: P / 4,6: M 1 /, 7: M 2 /, 8: M 3 /$, 9: M3/, 10: C-M3/in the Recent R. cystops (ISZ E-62/71, Luxor, Egypt). Click here for file

[http://www.biomedcentral.com/content/supplementary/14712148-7-165-S3.doc]

\section{Acknowledgements}

We thank Tereza Adamova, Masaa Al-Jumaily, Michal Andreas, D. Basuwayd, Vladimir Bejcek, Vladimir Hanak, Radek Lucan, Pavel Munclinger, Abdul Karim Nasher, Petra Nova, Jan Obuch, Antonin Reiter and Marcel Uhrin for their help in obtaining samples. Ron Blakey (Department of Geology, Northern Arizona University, Flagstaff) kindly permitted us to adopt his paleogeographic reconstruction for this paper. We are grateful to Emma Teeling, Bernard Sigé, and three anonymous reviewers for valuable comments and to Oldrich Fejfar and Stanislav Cermak for their help with anal- yses of the non-chiropteran fossils. Special thanks go to P. David Polly who carefully read and extensively improved the final version of the manuscript.

This work was supported by the Grant Agency of the Czech Republic (206/ 05/2334, 206/02/D04I), the Ministry of Education, Youth and Sports of the Czech Republic (MSMT 0021620828), and the Ministry of Culture of the Czech Republic (MK0000232720I).

\section{References}

I. Teeling EC, Scally M, Kao JD, Romagnoll ML, Springer MS, Stanhope $\mathrm{MJ}$ : Molecular evidence regarding the origin of echolocation and flight in bats. Nature 2000, 403:188-192.

2. Teeling EC, Madsen O, Van Den Bussche RA, de Jong WW, Stanhope MJ, Springer MS: Microbat paraphyly and the convergent evolution of a key innovation in Old World rhinolophoid microbats. Proc Natl Acad Sci USA 2002, 99: I 43 I - 436.

3. Teeling EC, Springer MS, Madsen O, Bates P, O'Brien SJ, Murphy WJ: A molecular phylogeny for bats illuminates biogeography and the fossil record. Science 2005, 307:580-584.

4. Koopman KF: Chiroptera: Systematics. Handbook of Zoology. Volume VIII. Mammalia Berlin and New York: Walter de Gruyter; 1994.

5. Hulva P, Horacek I: Craseonycteris thonglongyai (Chiroptera: Craseonycteridae) is a rhinolophoid: molecular evidence from cytochrome b. Acta Chiropterol 2002, 4: 107-120.

6. Van Den Bussche RA, Hoofer SR: Phylogenetic relationships among recent chiropteran families and the importance of choosing appropriate out-group taxa. I Mammal 2004, 85:32I-330.

7. Eick GN, Jacobs DS, Matthee CA: A nuclear DNA phylogenetic perspective on the evolution of echolocation and historical biogeography of extant bats (Chiroptera). Mol Biol Evol 2005, 22:1869-1886.

8. Hill JE: A review of the Rhinopomatidae (Mammalia: Chiroptera). Bull Brit Mus Natur Hist Zool 1977, 32:29-43.

9. Van Cakenberghe V, De Vree F: A revision of the Rhinopomatidae Dobson with the description of a new subspecies (Mammalia: Chiroptera). Senckenberg Biol 1872, 73:1-24.

10. Tschernov E: Faunal turnover and extinction rates in the Levant. In Quaternary Extinctions: A prehistoric revolution Edited by: Martin PS, Klein RG. Tucson: Univ. Arizona Press; 1984:528-552.

II. Dobson GE: Catalogue of the Chiroptera in the Collection of the British Museum London: British Museum; 1878.

12. Winge H: Pattedyr slaegter. (The interrelationship of the mammalian genera). Kopenhagen: CA Reitzels Forlag; 1941.

13. Koopman KF: Order Chiroptera. In Mammal Species of the World. A Taxonomic and Geographic Reference Edited by: Wilson DE, Reeder DM. Washington and London: Smithsonian Institution Press; 1993:|37-241.

14. Van Valen L: The Evolution of Bats. Evol Theory 1979, 4:103-12I. 
15. Simmons NB: Order Chiroptera. In Mammal Species of the World: A Taxonomic and Geographic Reference Volume I. Third edition. Edited by: Wilson DE, Reeder DM. Baltimore: The John Hopkins Univ Press; 2005:3 I 2-529.

16. Benda P, Hanak V, Andreas M, Reiter A, Uhrin M: Two new species of bats (Chiroptera) for the fauna of Libya: Rhinopoma hardwickii and Pipistrellus rueppellii. Myotis 2004, 4I-42:I09-I 24.

17. Benda P, Andreas M, Kock D, Lucan R, Munclinger P, Nova P, Obuch J, Ochman K, Reiter A, Uhrin M, Weinfurtova D: Bats (Mammalia: Chiroptera) of the Eastern Mediterranean. Part 4. Batfauna of Syria: distribution, systematics, ecology. Acta Soc Zool Bohem 2006, 70: I-329.

18. Ellerman JR, Morrison-Scott TCS: Checklist of the Palaearctic and Indian Mammals I 758 to 1946 London: British Museum (Natural History); I95I.

19. Harrison DL, Bates PJJ: TheMammals of Arabia Second edition. Sevenoaks: Harrison Zoological Museum; 1991.

20. Hey J: The mind of the species problem. Trends Ecol Evol 200I, 1 6:326-329.

21. Bradley RD, Baker RJ: A test of Genetic Species Concept: cytochrome-b sequences and mammals. J Mammal 200I, 82:960-973.

22. Baker RJ, Bradley RD: Speciation in mammals and the genetic species concept. J Mammal 2006, 87:643-662.

23. Ibanez C, Garcia-Mudarra JL, Ruedi M, Stadelmann B, Juste J: The Iberian contribution to cryptic diversity in European bats. Acta Chiropterol 2006, 8:277-297.

24. Mayer F, Dietz Ch, Kiefer A: Molecular species identification boosts bat diversity. Frontiers in Zoology 2007, 4:4

25. Qumsiyeh MB: The Bats of Egypt. Spec Publ Mus Texas Tech Univ 1985, 23:1-102.

26. Kock D: Die Fledermaus-Fauna des Sudan (Mammalia, Chiroptera). Abh Senckenberg Naturforsch Ges 1969, 52 I:I-238.

27. Anand Kumar TC: Reproduction in the rat-tailed bat Rhinopoma kinneari. J Zool Lond 1965, I47:|47-I55.

28. Thomas O: Scientific results from the Mammal Survey. No. XXII. A. A new bat of the genus Rhinopoma from S. E. Persia. J Bombay Natur Hist Soc 1920, 27:25.

29. Sigé B, Legendre S: L'histoire des peuplements de chiropteres du bassin méditerranéen: l'apport comparé des remplissages karstiques ez des dépot fluvio-lacustres. Mém Biospéleol 1983, 10:209-225.

30. Sigé B: Les chiropteres oligocenes du Fayum, Egypte. Geol Paleontol 1985, 19:16I-I89.

31. Remy JA, Crochet J-Y, Sigé B, Sudre J, de Bonis L, Vianey-Liaud M, Godinot M, Hartenberger J-L, Lange-Badré B, Comte B: Biochronologie des phosphorites du Quercy: Mise a jour des listes fauniques et nouveaux gisements de mammiferes fossiles. Müncher Geowiss Abh 1987, (A) 10:169-188.

32. Storch G: Order Chiroptera. In The Miocene Land Mammals of Europe Edited by: Rössner G, Heissig K. München: Pfeil Verl; 1999:81-90.

33. Sigé B: Les Insectivores et Chiropteres du Paleogene moyen d'Europe dans I'histoire des faunes de Mammiferes sur ce continent. J Palaeontol Soc India 1975, 20:178-190.

34. Hand S: Australian fossil bat diversity and evolution. Aust Mammal 1999, 2 I:34-45.

35. Sevilla P: Rhinolophoidea (Chiroptera, Mammalia) from the upper Oligocene of Carrascosa del Campo (Central Spain). Geobios 1990, 23:173-188.

36. Sigé B: Les Chiropteres oligocenes de St-Victor-la-Coste (Gard). Crsomm Soc Geol France 1967, I63:

37. Ziegler R: The bats (Chiroptera, Mammalia) from the Late Oligocene Fissure Fillings Herrlingen 8 and Herrlingen 9 near UIm (Baden-Württemberg). Senckenberg Lethaea 2000 80:642-683.

38. Sigé B, Thomas H, Sen S, Gheerbrant E, Roger J, Al-Sulaimani Z: Les chiropteres de Taqah (Oligocene inferieur, Sultanat d'Oman). Premier inventaire systématique. Müncher Geowiss Abh 1994, (A) 26:35-48.

39. Hand S: New Miocene megadermatids (Megadermatidae, Chiroptera) from Australia, with comments on megadermatid phylogenetics. Aust Mammal 1985, 8:5-43.

40. Sigé B: Rhinolophoidea et Vespertilionoidea (Chiroptera) du Chambi (Eocene inférieur de Tunisie). Aspects biostratigraphique, biogéographique et paléoécologique de l'origine des chiropteres modernes. $\quad N$ Jb Geol-Paläontol Abh 1991, I 82:355-376.

41. Horacek I: On the early history of vespertilionid bats in Europe: the Lower Miocene record from the Bohemian Massif. Lynx 200I, 32:I23-I54

42. Miller GS: The families and genera of bats. Bull US Nat/ Mus 1907 , 57:I-282.

43. Simmons NB, Geisler JH: Phylogenetic relationships of Icaronycteris, Archaeonycteris, Hassianycteris, and Palaeochiropteryx to extant bat lineages, with comments on the evolution of echolocation and foraging strategies in Microchiroptera. Bull Am Mus Natur Hist 1998, 232: I-182.

44. Habersetzer J, Richter G, Storch G: Paleoecology of early Middle Eocene bats from Messel, FRG. Aspects of flight, feeding and echolocation. Hist Biol 1994, 8:235-260.

45. Gunnell GF, Jacobs BF, Herendeen PS, Head JJ, Kowalski E, Msuya CP, Mizabwa FA, Harrison T, Hebersetzer J, Storch G: Oldest placental mammal from sub-Saharan Africa: Eocene microbat from Tanzania - evidence for early evolution of sophisticated echolocation. Palaeontologia Electronica 2005, 5: I-I0.

46. Böhme M: The Miocene Climatic Optimum: evidence from ectothermic vertebrates of Central Europe. Palaeogeog Palaeoclimat Palaeoecol 2003, I 95:389-40I.

47. Harzhauser M, Piller WE, Steininger F: Circum-Mediterranean Oligo-Miocene biogeographic evolution - the gastropods' point of view. Palaeogeog Palaeoclimat Palaeoecol 2002 193:103-133.

48. Hrbek T, Meyer A: Closing of the Tethys Sea and the phylogeny of Eurasian killifishes (Cyprinodotiformes: Cyprinodontidae). J Evol Biol 2003, 16:17-36

49. Darlington PJ: The geographical distribution of animals. New York and London: Wiley; 1957.

50. Lattin de G: Grundriss der Zoogeographie Jena: Gustav Fischer Verl; 1967.

5I. Rögl F: Palaeogeographic Considerations for Mediterranean and Paratethys Seaways (Oligocene to Miocene). Ann Naturhist Mus Wien 1999, 99A:279-310.

52. Dawson MR: Paleogene rodents of Eurasia. Deinsea 2003, I0:97-I26.

53. Tschernov E: Eurasion-African biotic exchanges through the Levantine corridor during the Neogene and Quaternary. Cour Forsch-Inst Senceknberg 1992, I 53:103-I 23.

54. Koufos GD: Late Miocene mammal events and biostratigraphy in the Eastern Mediterranean. Deinsea 2003, 10:343-37I.

55. Koufos GD, Kostopoulos DS, Vlachou TD: Neogene/Quaternary mammalian migrations in Eastern Mediterranean. Belg J Zool 2005, 135:181-190.

56. Corbet GB, Hill JE: The Mammals of the Indomalayan Region: a Systematic Review London: Oxford Univ Press; 1992.

57. Swofford DL: PAUP* 4.0b/0 Sunderland: Smithsonian Institution; 2001 .

58. Xia X, Xie Z, Salemi M, Chen L, Wang Y: An index of substitution saturation and its application. Mol Phylogenet Evol 2003, 26: I-7.

59. Daugbjerg N, Andersen RA: Phylogenetic analyses of the rbcL sequences from haptophytes and heterokont algae suggest their chloroplasts are unrelated. Mol Biol Evol 1997, |4:|242-|25|.

60. Posada D, Crandall KA: Modeltest: testing the model of DNA substitution. Bioinformatics 1998, |4:817-8|8.

6I. Kawai K, Nikaido M, Harada M, Matsumura S, Lin LK, Wu Y, Hasegawa $M$, Okada $N$ : The status of the Japanese and East Asian bats of the genus Myotis (Vespertilionidae) based on mitochondrial sequences. Mol Phylogenet Evol 2003, 28:297-307.

62. Huelsenbeck JP, Ronquist FR: MRBAYES: Bayesian inference of phylogenetic trees. Bioinformatics 200I, I 7:754-755.

63. Takezaki N, Rzhetsky A, Nei M: Phylogenetic test of the molecular clock and linearized trees. Mol Biol Evol 1995, 12:823-833.

64. Huelsenbeck JP, Crandall KA: Phylogeny estimation and hypothesis testing using maximum likelihood. Ann Rev Ecol Syst 1997, 28:437-466.

65. McKenna MC, Bell SK: Classification of Mammals Above the Species Level New York: Columbia Univ. Press; 1997.

66. Blakey R: Palaeogeographic reconstructions of the Mediterranean region. [http://www2.nau.edu/rcb7/] 